\title{
Crack Propagation of Metal Powder Compact
}

Suraya Mohd Tahir, Ahmad Kamal Ariffin, Norhamidi Muhamad and Nik Abdullah Nik Mohamed

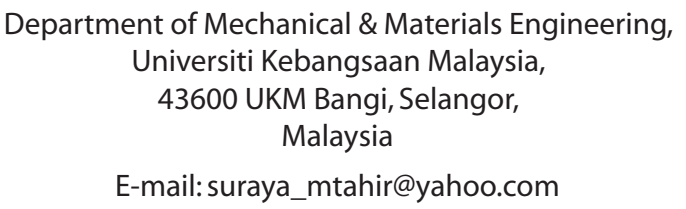

Received Date: $28^{\text {th }}$ August 2006 Accepted Date: $7^{\text {th }}$ March 2007

\begin{abstract}
Simulation of crack propagation in metal powder during the cold compaction process is presented in this paper. Based on a fracture criterion of granular materials in compression, a displacement based finite element model has been developed to simulate the fracture process in a multi level component made of iron powder. Estimation of fracture toughness variation with relative density is established in order to provide the fracture parameters as compaction proceeds. A finite element model with adaptive remeshing technique is used to accommodate changes in geometry during the compaction and fracture process, while friction between crack faces is modelled using the six nodes isoparametric interface elements. Two widely used yield criteria for powder compact, namely Mohr-Coulomb and Elliptical cap are used in the models. Different crack growth patterns obtained by using these two yield criteria are presented and compared in terms of the influence of shear stress and relative density distributions. Even though the crack starts at different compaction step and different crack patterns are obtained when different yield criteria is used, shear crack is predicted to starts in the region with lower relative density and higher shear stress in both models.
\end{abstract}

Keywords: Powder compact, fracture criteria, fracture toughness, finite element.

\section{ABSTRAK}

Penyelakuan perambatan retak semasa proses pemadatan serbuk logam dibentangkan di dalam kertas ini. Berdasarkan kriteria retak bagi bahan serbuk termampat, model unsur terhingga berdasarkan anjakan telah dibangunkan untuk menyelaku proses keretakan dalam komponen berbilang aras yang dihasilkan daripada serbuk besi. Anggaran hubungan keliatan retak dengan ketumpatan relatif dibangunkan sebagai parameter retak semasa proses pemadatan dijalankan. Model unsur terhingga dengan teknik penjaringan adaptif digunakan bagi menangani masalah perubahan geometriyang besar semasa proses pemadatan dan keretakan, manakala geseran antara muka retak dimodelkan dengan menggunakan unsur antaramuka enam nod separameter. Dua jenis kriteria alah yang biasa digunakan bagi serbuk terpadat, iaitu Mohr-Coulomb dan tukup elips telah digunakan. Corak perambatan retak berbeza yang diperolehi dengan menggunakan kedua-dua jenis kriteria alah tersebut telah dibentangkan dan dibandingkan dari segi pengaruh taburan 
tegasan ricih dan ketumpatan relatif. Meskipun retak bermula pada langkah pemadatan yang berbeza dan corak pemadatan yang berbeza diperolehi apabila kriteria alah yang berbeza digunakan, retak ricih diramalkan bermula di kawasan yang berketumpatan rendah dan mempunyai tegasan ricih yang tinggi bagi kedua-dua jenis model.

Kata kunci : Serbuk padat, kriteria patah, kekuatan patah, unsur terhingga.

\section{INTRODUCTION}

Manufacturing parts using powder metallurgy (PM) involves four major steps: powder and lubricant mixing, compacting powders into appropriate shapes in closed dies to produce green compacts, sintering the green compacts at elevated temperature and finally, postsintering secondary operations (Chtourou et al. 2002). Details on cold compaction process can be found in (Ariffin 1995), where the numerical modelling of the complete cycle has been developed, and validated by experiments. In modelling the compaction process, the macromechanical modelling approach is used in this work, where the powder medium is considered as a continuum that undergoes large elasticplastic deformation. Constitutive model based on granular material is used since powder behaves similarly to a frictional granular material with regard to dilatancy and densification behaviour (Gollion et al. 1989).

Extensive literature reviews on materials under compression reveal that generally crack grows in mode II, no matter whether the material is brittle or ductile as reported by Arun Roy et al. (1999), Isaksson and Stahle (2002 \& 2003), De Bremaecker and Feris (2004). However, crack patterns are being influenced by the amount of

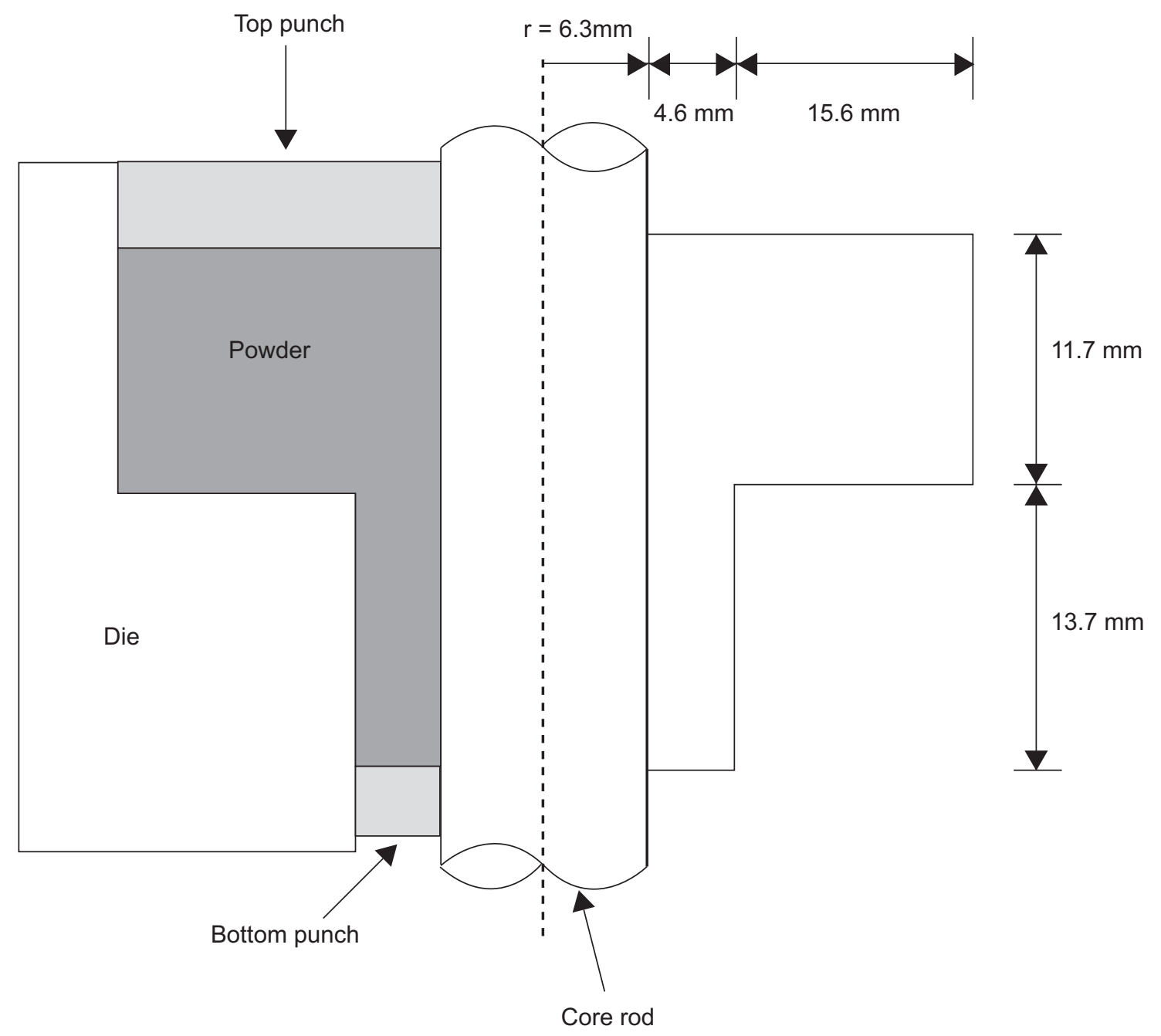

FIGURE 1. Geometry and boundary conditions of a rotational flanged component 


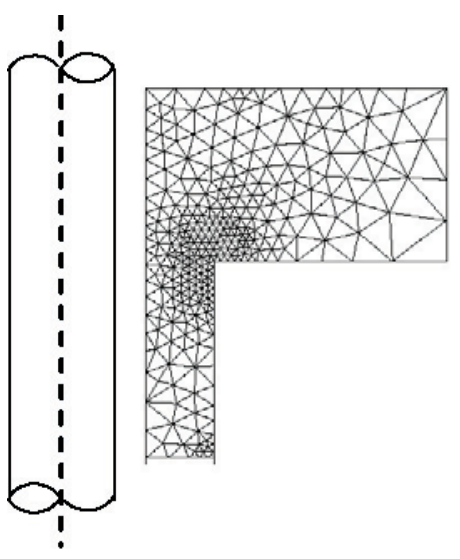

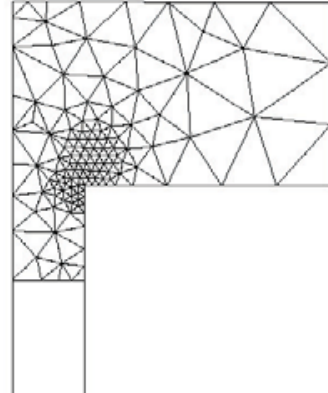

(b) Step 20

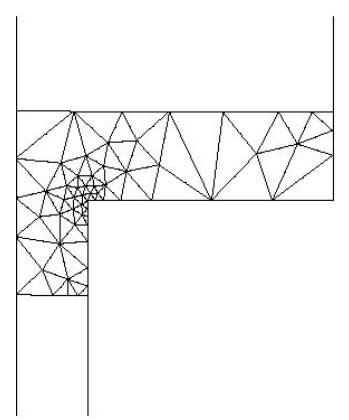

(c) Step 40

FIGURE 2. Axisymmetric representation of compaction process at (a) Step 1; (b) Step 20 ; and (c) Step 40

applied stress, and friction between the crack surfaces. In this paper a suitable fracture criterion for metal powder during cold compaction process is outlined, taking into accounts the mechanical behaviour of metal powder under compaction process. Finite element modelling of the crack initiation and propagation has been developed using FORTRAN programming language, where two different yield criteria namely Mohr-Coulomb and elliptical cap (Roscoe \& Burland 1968) yield criteria which are originally developed for soil mechanics, are used for powder material.

\section{MODELLING OF FRACTURE IN POWDER COMPACT}

A multi level component, in this case a rotational flanged component, is modelled by an axisymmetric representation as shown in Figures 1 and 2. Iron powder with material properties as listed in Aidah (2001) is compacted by bottom and to punch movements. Total displacement of the bottom punch, $d_{b}=7.69 \mathrm{~mm}$ while the top punch, $d_{t}=6.06 \mathrm{~mm}$ at the end of compaction process.

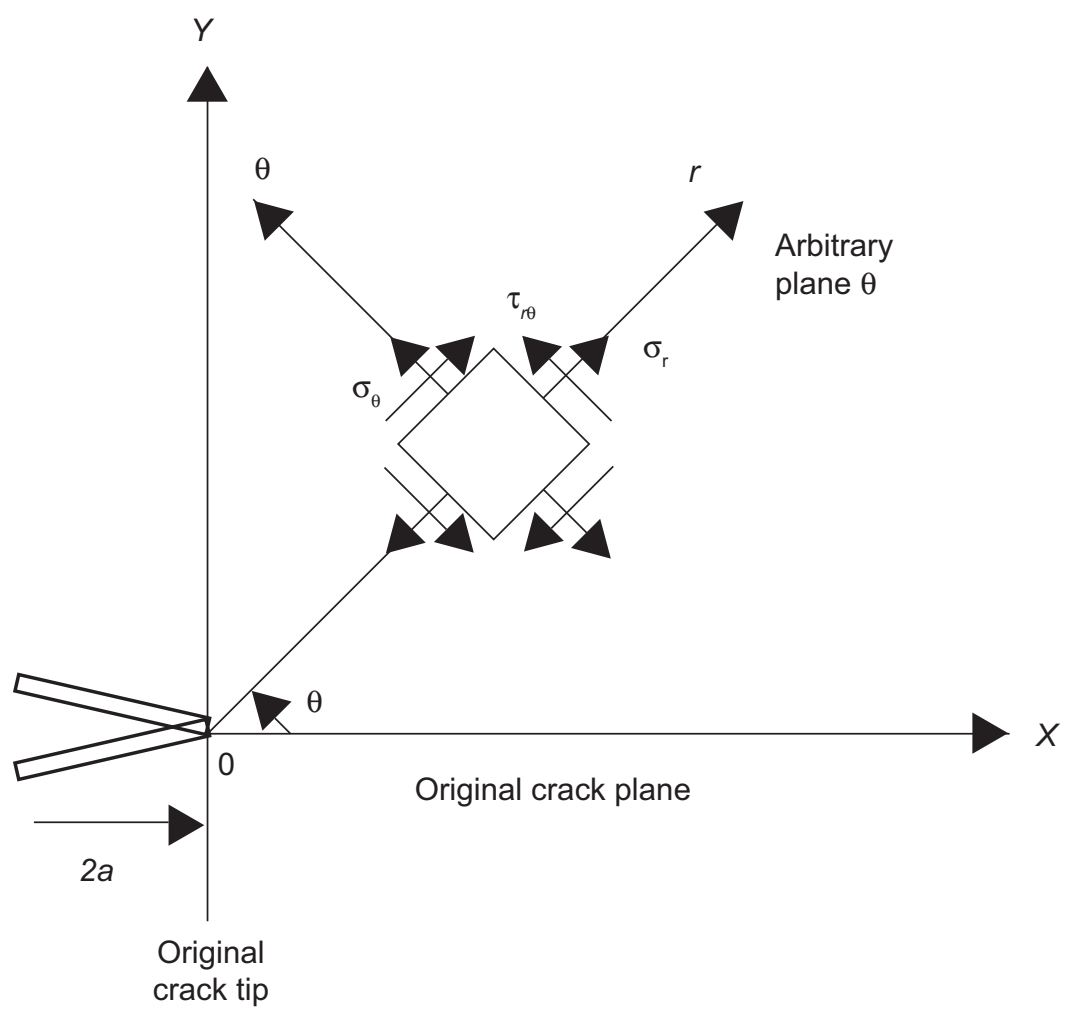

FIGURE 3. Stress component at a point near a crack tip in the polar coordinate system 


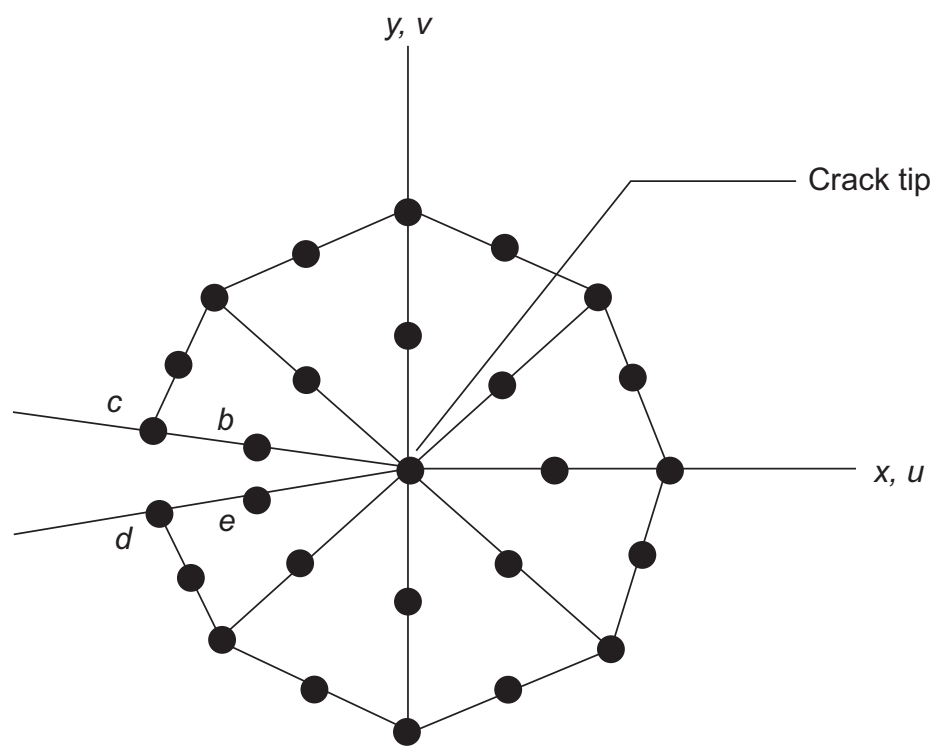

FIGURE 4. Nodes around the crack tip for calculation of the stress intensity factors

In this work, the compaction is performed in 20 steps movement of bottom and top punch respectively, and in turn as shown in Figure 2.This mean that a total displacement of $7.69 \mathrm{~mm}$ is first achieved when the bottom punch had finished a 20 steps movement (step 1 to 20), followed by a total displacement of $6.06 \mathrm{~mm}$ by the top punch after a 20 steps movement (step 21 to 40 ).

\section{FRACTURE CRITERIA}

Even though it is believed that failure in metal powder compaction is due to shear fracture (mode II), the fracture criterion in need must not neglect the possibility of fracture due to opening mode (mode I). Since powder behave similarly to frictional granular materials like rock in compression, fracture criteria by Quihua et al. (2003) is adopted in this work. Based on the examination of mode I and mode II stress intensity factors on the arbitrary plane $\theta$ based on the stress component near a crack tip as in Figure $2, K_{l}(\theta)$ and $K_{\|}(\theta)$, varying with $\theta\left(-180^{\circ}\right.$ $\left.\leq \theta \leq+180^{\circ}\right)$, no matter what kind of loading condition is applied, the fracture criterion (Quihua et al.2003) stated that for mode I fracture to occur:

$$
1<\frac{K_{l I \max }}{K_{l \max }}<\frac{K_{l l c}}{K_{l c}}, K_{l \max }=K_{l c} \text { at } \theta_{l c}
$$

For mode II fracture:

$$
\frac{\mathrm{K}_{\| / \max }}{\mathrm{K}_{/ \text {max }}}>\frac{\mathrm{K}_{\| / c}}{\mathrm{~K}_{l c}}, \mathrm{~K}_{\| / \max }=\mathrm{K}_{\| / c} \text { at } \theta_{/ l c}
$$

In order to determine $K_{l \text { max }}$ and $K_{I I \max }$ in equations ( 1 ) and (2), mode I and mode II stress intensity factors in the direction of $\theta$ is defined as:

$$
\begin{gathered}
K_{l}(\theta)=K_{l} \cos ^{3} \frac{\theta}{2}+K_{I I}\left(-\sin \frac{\theta}{2} \cos ^{2} \frac{\theta}{2}\right) \\
K_{I /}(\theta)=K_{l} \sin \frac{\theta}{2} \cos ^{2} \frac{\theta}{2}+K_{I I} \cos \frac{\theta}{2}\left(1-3 \sin ^{2} \frac{\theta}{2}\right)
\end{gathered}
$$

$K_{l}(\theta)$ and $K_{\| l}(\theta)$ are calculated on the mid nodes around the crack tip as shown in Figure 4 to obtain the maximum $K_{I \text { max }}$ and $K_{\| / \text {max }}$ where $\theta$ is defined as positive in the anticlockwise direction from the original crack plane. $K_{l}$ and $K_{\|}$ in equations (3) and (4) are the stress intensity factors in the original crack plane. In finite element method, these values can be calculated using the displacement correlation technique (Phan et al. 2003) as below:

$$
K_{l}=\frac{G}{\kappa+1} \sqrt{\frac{2 \pi}{L}}\left(\left(4\left(v_{b}-v_{d}\right)-\frac{\left(v_{c}-v_{e}\right)}{2}\right)_{(5)}\right.
$$




$$
K_{\text {II }}=\frac{G}{\kappa+1} \sqrt{\frac{2 \pi}{L}}\left(\left(4\left(u_{b}-u_{d}\right)-\frac{\left(u_{c}-u_{e}\right)}{2}\right)_{(6)}\right.
$$

where $G$ is the shear modulus, $L$ is the element length, $\kappa$ is defined as $\kappa=(3-4 v)$ for plane strain or axisymmetric problem, where $v$ is the Poisson's ratio. The $u$ and $v$ are the displacement components in $x$ and $y$ directions respectively, where the subscripts indicate their positions as shown in Figure 4.

\section{ADAPTIVE MESH AND CRACK MECHANISM}

An adaptive finite element mesh using error estimator based on stress error norm (Zienkiewicz $\&$ Zhu 1989) is used, where automatic remeshing is calculated at each step during the compaction process. Equations (3) and (4) are used to calculate the stress intensity factor (SIF) of mode I $\left(K_{l}\right)$ and mode II $\left(K_{I I}\right)$. These values are calculated on the nodes around the crack tip and crack is modelled to propagate inter-element (Bouchard et al. 2000), by splitting mechanism of crack tip node in order to provide two adjacent crack faces. This is similar to the release node mechanism except that the direction of crack propagation is depending on direction criteria.

\section{FRICTION CRITERIA}

Coulomb friction law which is often adopted in friction problems is used in this work, given by:

$$
F_{f}\left(\tau, \sigma_{n}\right)=|\tau|+\mu \sigma_{N}
$$

where $\tau$ is the friction shear stress, $\sigma_{N}$ is the normal stress which should be compressive for friction to developed, and $\mu$ is the coefficient of friction. Six nodes isoparametric elements (Ariffin 1995) are used as interface elements for friction between powder material and die wall during the compaction process, as well as to model friction on the crack faces in contact.

\section{MODE I FRACTURE TOUGHNESS ( $\left.K_{I C}\right)$}

Based on approximate formulas for mode I fracture toughness ( $K_{l C}$ ) by Gibson and Ashby (1988), finite element models have been developed by Choi and Sankar (2003) to estimate the variation of $K_{c C}$ as a function of solidity of carbon foam. By assuming that the crack is parallel to one of the principal material axes, $K_{k C}$ can be estimated using the following formula:

$$
K_{I C}=\frac{\sigma_{U S}}{\sigma_{\max }}
$$

where $\sigma_{u s}$ is the strength of the material and $\sigma_{\max }$ is the maximum principal stress. Study on mechanical properties of iron compact has been performed by Poquillon et al. (2002), which provide the variation of green strength with relative density as shown in Figure 5. Using

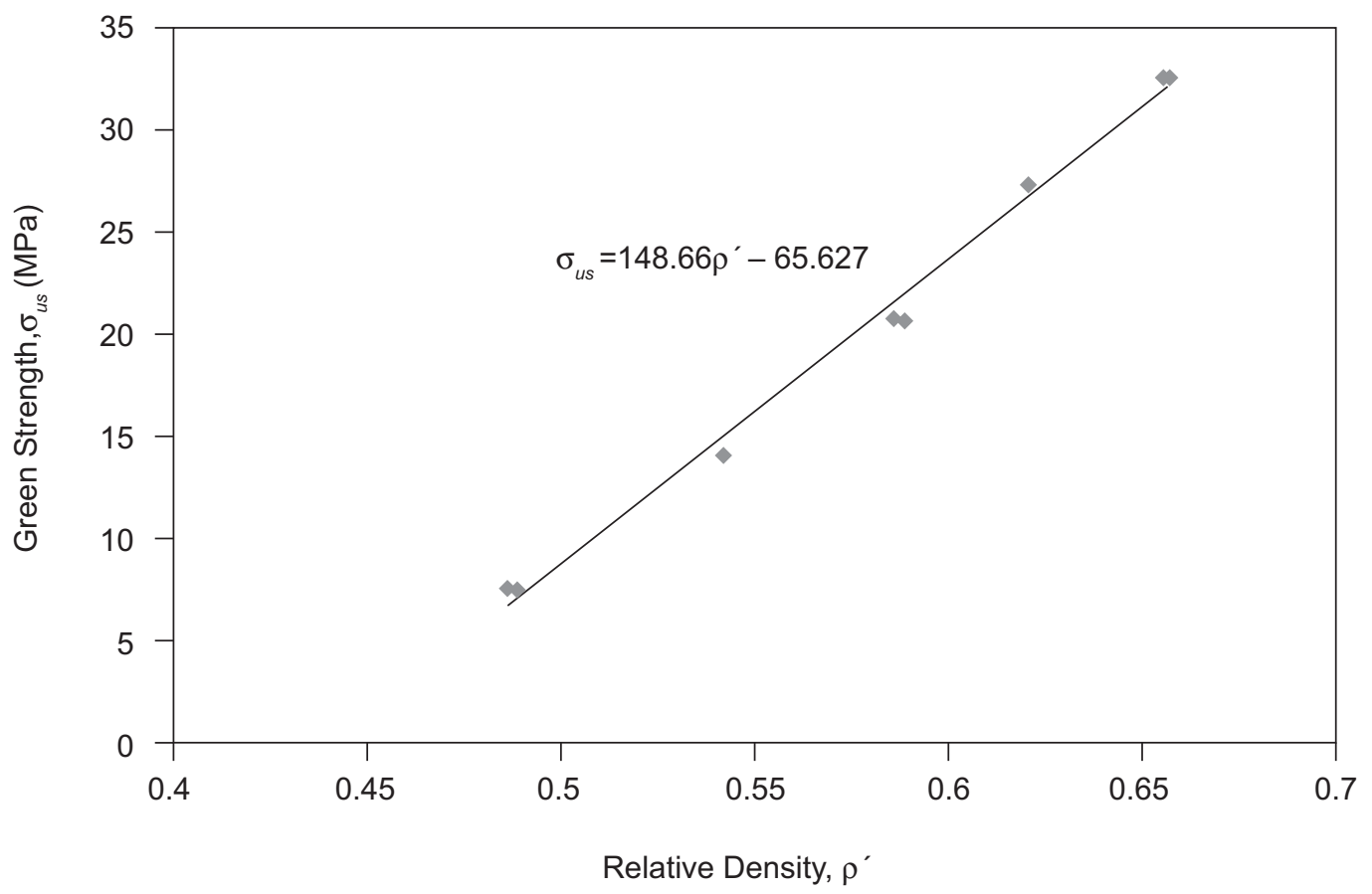

FIGURE 5. Variation of green strength with relative density 


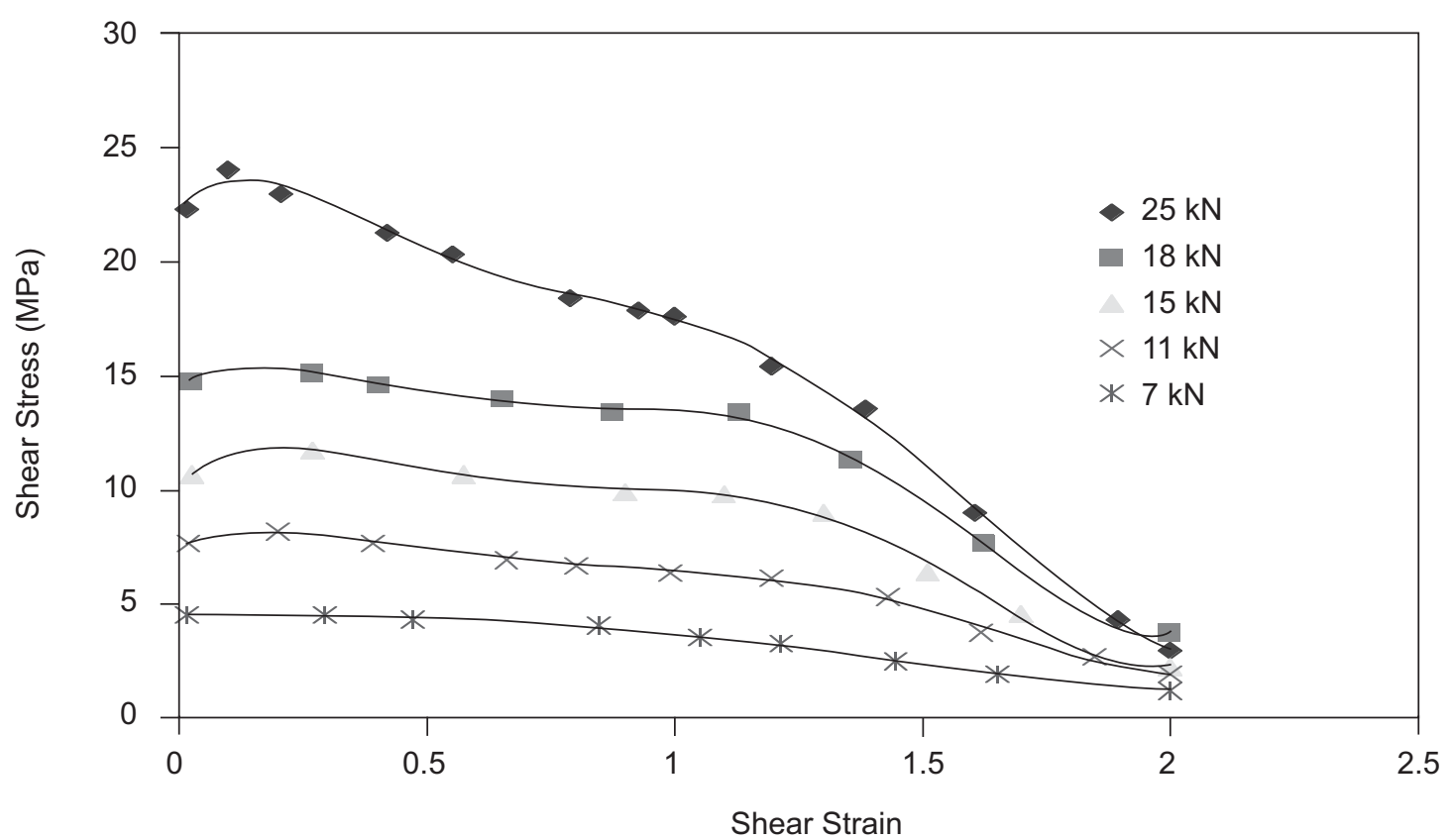

FIGURE 6. Shear stress-strain curves for compacts with different final compaction load

the variation of green strength, equation (8) becomes:

$$
K_{I C}=\frac{148.6 \rho^{\prime}-6.627}{\sigma_{\max }}
$$

where $\rho^{\prime}$ is the relative density of the iron compact with respect to solid iron.

\section{MODE II FRACTURE TOUGHNESS $\left(\mathrm{K}_{\mathrm{IIC}}\right)$}

Fracture toughness of a material is the amount of energy a material can absorbs before fracture, or energy required to create new crack surfaces. Thus it is also equal to the area under stress-strain curve up to fracture. Experimental data by Aidah (2001) is used in this work to obtain the shear stress-strain curves at different compaction load as in Figure 6, and subsequently used to estimate the variation of mode II fracture toughness $\left(K_{I I C}\right)$ with relative density as depicted in Figure 7, given by:

$$
K_{\text {IIC }}=0.1174 e^{6.5031 \rho^{\prime}}
$$

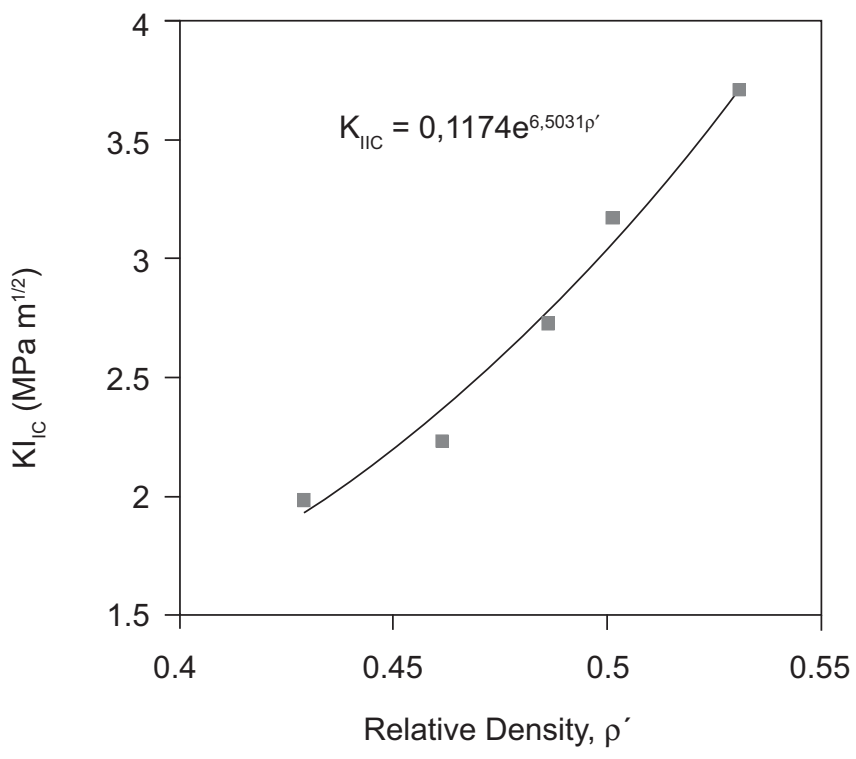

FIGURE 7. Variation of $K_{\text {IIC }}$ with relative density 
where $\rho^{\prime}$ is the relative density of iron compact at the point with maximum $K_{\| \prime}$

\section{RESULT AND DISCUSSION}

Since no pre-crack is present in this case, the direction of maximum shear stress is used as the original crack direction, in the calculation of $K_{l}(\theta)$ and $K_{I I}(\theta)$ for the first crack formation. This is acceptable because the same conclusions regarding the crack path are achieved in materials under compression, by assuming that crack grows along the plane of maximum shear stress as by assuming that crack follows the direction of maximum $K_{\| I}$ (Isaksson \& Stahle 2003). Without pre-crack in this work, the point with maximum shear stress is taken as the point where the crack starts.

A single crack initiated from the boundary surface is considered in this work. Simulation of the fracture process show that shear crack starts at the end of step 9 when Mohr-Coulomb yield criteria is used. The shear stress and relative density distributions at step 10 are shown in Figures 8(a) and 9(a) respectively. From these two figures, it can be seen that crack starts in the region with the highest shear stress distribution, but lowest relative density distribution. Similarly, Figures 10(a) and 11(a) show that by using the elliptical cap yield criteria, shear crack starts at a point with maximum shear stress but in the region where the relative density is much lower. In this case however, crack starts at the beginning of compaction by the top punch movement (step 21), where compaction by the bottom punch had complete, causing the lower part of compacted powder to have much higher relative density distribution as shown in Figure 11 (a).

As compaction proceeds, simulations of crack propagation show that different crack patterns are obtained by using different yield criteria. Crack propagation directions by using the two yield criteria are listed in Table 1, including the relative density at the point where crack first starts to propagate. No further crack propagation occurs after step 20 when Mohr-Coulomb criteria is used, while crack propagates only once when elliptical cap criteria is used.

The value of $\theta$ is calculated with respect to the earlier crack direction, using the sign convention as shown in Figure 3, while $\rho^{\prime}$ is the relative density value at the point where crack propagates. These values of $\theta$ as listed in Table
1 show that the crack always extended away from the original crack direction. Neglecting the sign convention which indicates the direction of stresses, it can be seen from Figure 8(a) to Figure 8(b) and Figure 9(a) to Figure 9(b) that the crack propagates in the direction where the shear stress and relative density are much higher. Since relative density increases as compaction pressure increases (Aidah 2001, Poquillon et al. 2002), it can be deduced that the crack grows in the direction of higher compaction pressure. This is in line with the conclusion made by Arun Roy et al. (1999) which argue that crack grows in the direction of higher confining hydrostatic pressure or compaction pressure in this case.

By using the elliptical cap yield criteria which permits representation of densification as well as hardening, the predicted crack propagation direction is only $\approx+2^{\circ}$ away from the original crack plane. This is almost in the plane of original crack direction, as shown in Figure 10(b) and Figure 11 (b). In addition, the crack starts at the end of step 21 and propagates at step 25, which is much later compared to the previous case where crack starts at step 9 when Mohr-Coulomb yield criteria is used.

The numerical and experimental reports by previous researchers only provide the analysis in terms of crack direction when the crack first starts to propagate. Hence for comparison purposes, the value of relative density at which the crack first starts to propagate is given in Table 1 when two different yield criteria are used. It can be seen from Table 1 that the crack propagation direction is much nearer to the original crack plane when crack starts to propagate at a point with much higher relative density, which also implies a much higher compaction pressure. This is indeed agreed very well with the conclusion by Isaksson and Stahle (2003), which stated that the direction of the crack growth with respect to the original crack plane decreases with increasing pressure.

Due to the movement of the bottom punch in the first 20 steps, the two regions with the highest and lowest relative density are formed around the sharp corner, providing a high density gradient and causes the crack to propagates in such direction as shown in Figure 9 and Figure 11. The shear stresses which are initially higher at the boundary as shown in Figure 8(a) and Figure 10(a) become much lower as compaction proceeds, while the region with higher shear stresses is formed slightly centred, near the sharp 
TABLE 1. Details of crack propagation

\begin{tabular}{ccccccc}
\hline \multicolumn{2}{c}{ Using Mohr-Coulomb Criteria } & \multicolumn{3}{c}{ Using Elliptical Cap Criteria } \\
\hline Compaction Step & $\theta^{\circ}$ & $\rho^{\prime}$ & Compaction Step & $\theta^{\circ}$ & $\rho^{\prime}$ \\
\hline 17 & +22.7883 & 0.205084 & 25 & +2.150406 & 0.524965 \\
18 & +5.34889 & 0.353035 & & & \\
20 & +13.74237 & 0.557248 & & & \\
\hline
\end{tabular}

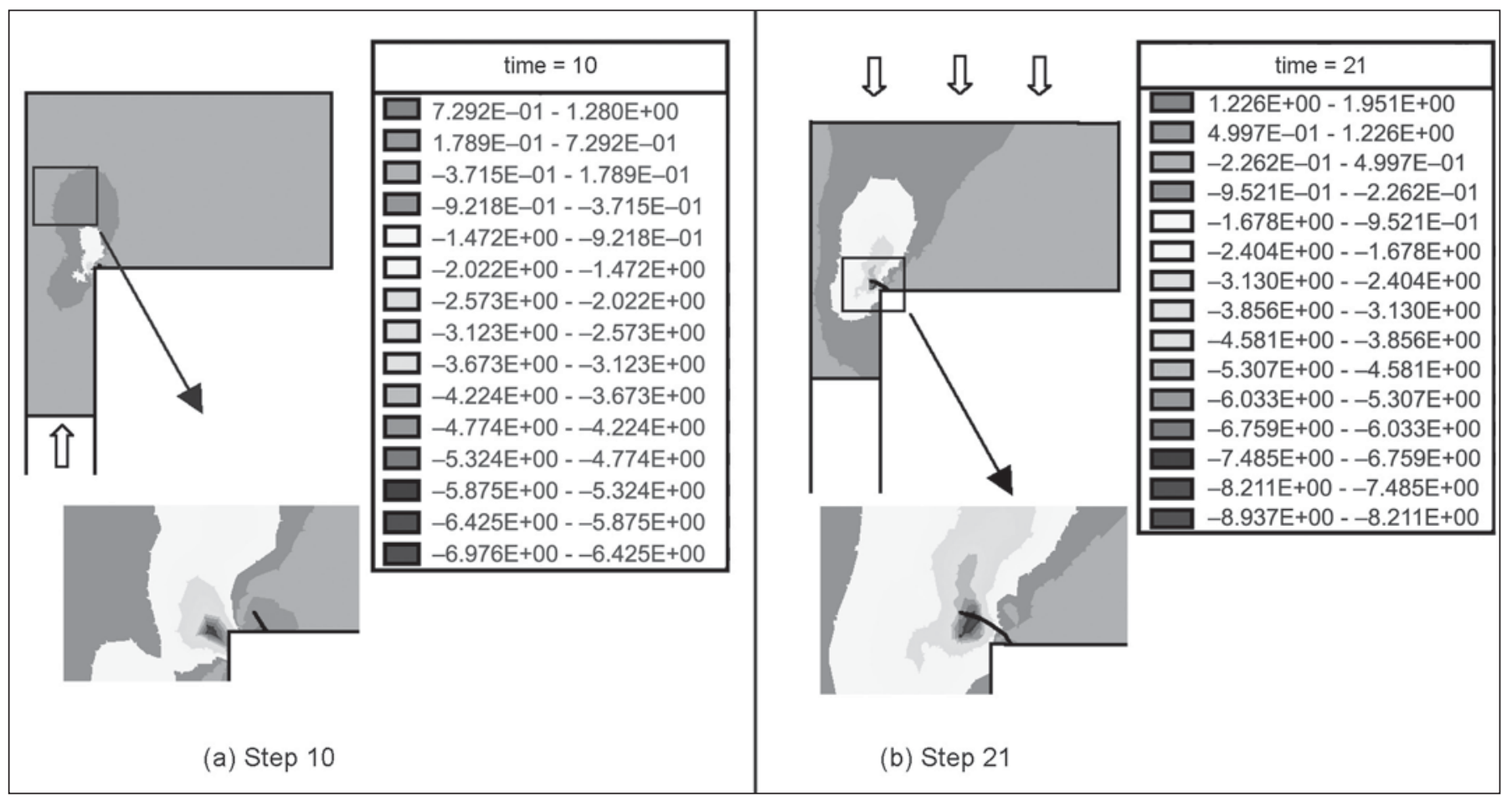

FIGURE 8. Shear stress distribution using Mohr-Coulomb yield criteria

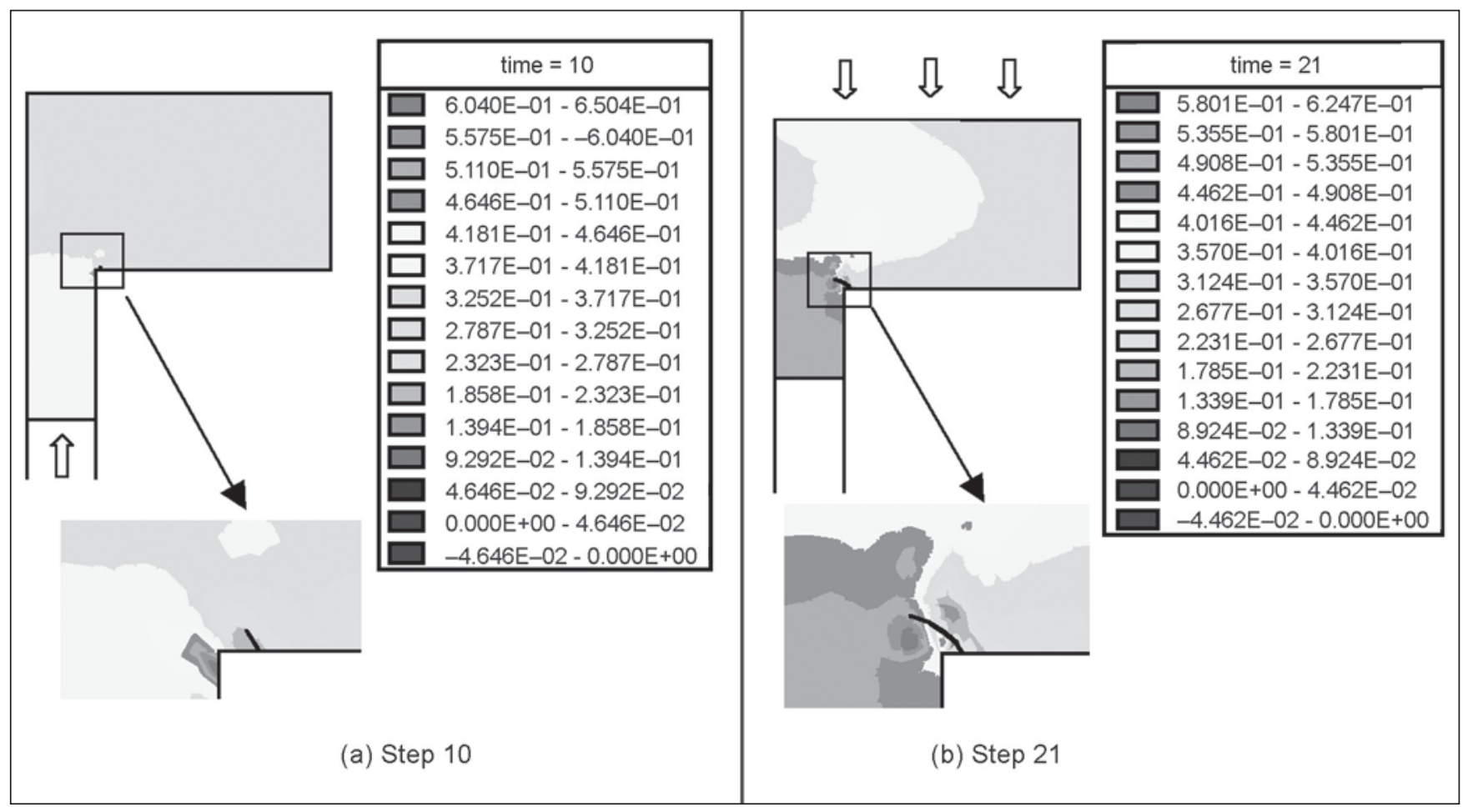

FIGURE 9. Relative density distribution using Mohr-Coulomb yield criteria 


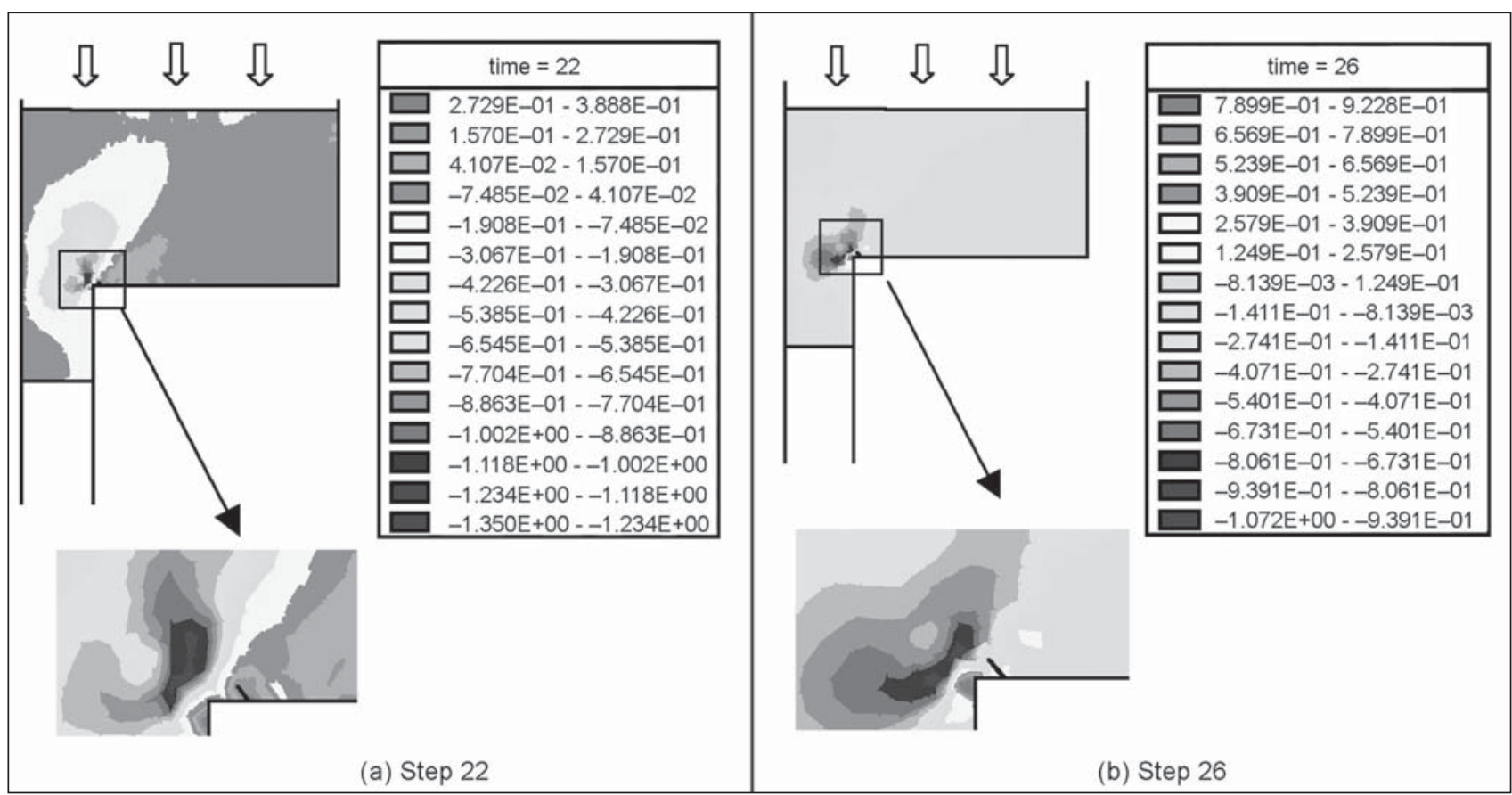

FIGURE 10. Shear stress distribution using elliptical cap yield criteria

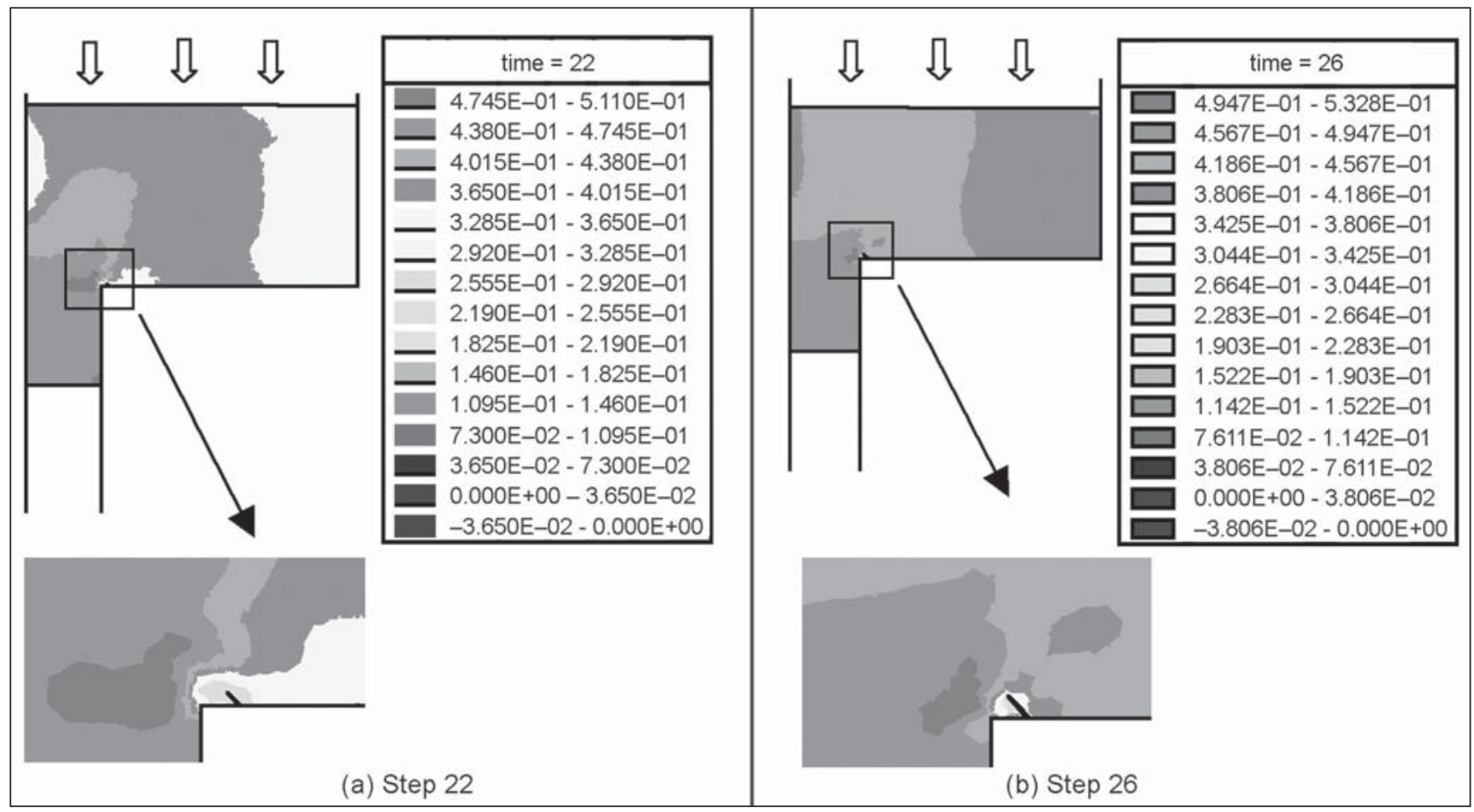

FIGURE 11. Relative density distribution using elliptical cap yield criteria

corner as shown in Figure 8(b) and Figure 10(b). As the consequence, the crack propagates inward starting from the boundary, towards the region where the shear stresses are much higher.

\section{CONCLUSION}

A displacement based finite element model has been developed to analyse the crack initiation and propagation in a multi level component made of iron powder, during the cold compaction process. Two different yield criteria namely the Mohr-Coloumb and elliptical cap yield criteria have been used in the model. Shear crack is predicted to starts in the region with lower relative density and higher shear stress in both models. Even though the crack starts at different 
compaction step and different crack patterns are obtained when different yield criteria is used, crack is predicted to starts at about the same point near the sharp inner corner of the component in the two different models. As compaction proceeds, the crack propagates in the direction where the shear stress and the relative density are much higher. Propagation of the crack towards the region of much higher relative density distribution also implies that

\section{REFERENCES}

Aidah Jumahat.2001. Analysis of Thermo-Mechanical Behaviour of Warm Compaction Process (In Malay Language), Master of Science Thesis, Universiti Kebangsaan Malaysia, Malaysia.

Ariffin A.K. Mohd. Ihsan. 1995. Powder Compaction, Finite Element Modelling and Experimental Validation, PhD Thesis. University of Wales Swansea, United Kingdom.

Arun Roy, Y., Narasimhan, R., Arora, P.R. 1999. An Experimental Investigation of Constraint Effects on Mixed Mode Fracture Initiation in A Ductile Aluminium Alloy, Acta Mate., 47: 1587-1596.

Bouchard, P.O., Bay, F., Chastel, Y. \& Tovena, I. 2000. Crack Propagation Modelling Using an Advance Remeshing Technique. Comput. Methods. Appl. Mech. Engineering, 189: 723-724.

Choi, S., Sankar, B.V. 2003. Fracture Toughness of Carbon Foam, Journal of Composite Materials, 37(23): 2101-2116.

Chtourou, H., Guillot, M.\& Gakwaya, A.2002.Modelling of The Metal Powder Compaction Process Using The Cap Model. Part 1: Experimental Material Characterisation and Validation. International Journal of Solids and Structures, 39:1059-1075.

De Bremaecker, J.Cl. \& Ferris, M.C. 2004. Numerical Models of Shear Fracture Propagation. Engineering Fracture Mechanics, 71: 2161-2178.

Gibson, L.J. and Ashby, M.F. 1988. Cellular Solids: Structure and Properties, Second Edition, Cambridge University press, Cambridge, United Kingdom.

Gollion, J., Bouvard, D. \& Stutz, P. 1989. On the Rheology of Metal Powder During Cold Compaction. Proc. Int. Conf. Micromechanics of Granular Media, the crack grows in the direction of higher compaction pressure, which is in line with the conclusion made by previous researchers on crack growth in materials under compression. By using the elliptical cap yield criteria which permits representation of densification as well as hardening, the crack propagates only once and the crack propagation direction is almost in the plane of original crack direction.

Powder and Grains, Ed. J. Biarez and R. Gourves, pp. 433-438.

Isaksson, P.\& Stahle, P.2002. Mode II Crack Paths Under Compression in Brittle Solids -A Theory and Experimental Comparison. International Journal of Solids and Structures, 39:2281-2297.

Isaksson, P. \& Stahle, P. 2003. A Directional Crack Path Criterion for Crack Growth in Ductile Materials Subjected to Shear and Compressive Loading Under Plane Strain Conditions. International Journal of Solids and Structures. 40: 3523-3536.

Phan, A.V., Napier, J.A.L., Gray, L.J. \& Kaplan, T. 2003. Stress intensity factor analysis of friction sliding at discontinuity interfaces and junctions. Computational Mechanics 32(4-6): 392-400.

Poquillon, D., Baco-Carles, V., Tailhades, Ph., Andrieu, E. 2002. Cold Compaction of Iron PowdersRelations Between Powder Morphology and Mechanical Properties Part II. Bending Tests: Results and Analysis, Powder Technology, 126: 75- 84.

Roscoe, K.H. \& Burland, J.B. 1968. On the Generalized Stress-Strain Behaviour of Wet Clay, Engineering Plasticity, Eds. Hayman \& Leckis, Cambridge University Press, Cambridge England: 535-609.

Quihua Rao, Zongqi Sun, O. Stephansson, Chunlin Li \& B. Stillborg. 2003. Shear Fracture (Mode II) of Brittle Rock.,Int. Journal of Rock Mechanics \& Mining Mining Sciences, 40:355-375.

Zienkiewicz, O.C. \& Zhu, J.Z. 1989. Error Estimates and Adaptive Refinement for Plate Bending Problems. Int. Journal for Numerical Methods in Engineering, 28: 2839-2853. 